\title{
THE CONCEPT OF PEACE IN THE QUR'AN:
}

\section{A SOCIO-THEMATIC ANALYSIS OF MUSLIMS' CONTESTATION IN SALATIGA, INDONESIA}

\author{
Adang Kuswaya \\ State Institute for Islamic Studies Salatiga \\ dangkuswaya@gmail.com \\ Muhammad Ali \\ University of California Riverside \\ muhammad.ali@ucr.edu
}

\begin{abstract}
This research aims not only to understand the concept of peace in the Qur'an but also analyze Muslims' contestation in Salatiga to lead to a peaceful life among religious believers. It requires an in-depth examination on dialectical perspectives between the ideal concept of peace in the Quran and the reality of a peaceful culture in the public sphere. Methodologically, this research combines literature review and semi-structured interviews to gather theoretical data based on social responses and literature of contemporary Qur'anic interpretation. The research subjects consist of (1) Muslims living with nonMuslim family members in the same house, (2) Muslims in a non-Muslim neighborhood, (3) religious figures, and (4) nonMuslims with Muslim family members. In order to interpret a special meaning of Qur'anic terms related to peaceful life, this research employs a hermeneutical approach of socio-thematic interpretation of the Qur'an. In conclusion, this research points out that Muslims in Salatiga play a significant role in
\end{abstract}


building a peaceful life where some concepts, such as unity, freedom, honesty, and respect, are principles thriving vividly throughout society. Additionally, tolerance is a foundation of social interaction leading them to cooperate. Besides, several values, namely harmonization, tolerance, and coexistence, can be seen as dominant ideas within the communities, and practices such as cooperation and friendship can also be seen in their daily life. Thus, this research affirms that the Muslim majority can lead to tolerance and accommodate diversity as a way of life.

Keywords: Muslims in Salatiga, peaceful life, interfaith, tolerance, the Quran.

\section{A. Introduction}

Peace is one of the fundamental human needs and all creatures even crave a peaceful life. It leads to making peace is a shared responsibility to create the peaceful life amidst diversity (Hanafi, 2000). Peace is an action or condition necessarily to control both emotion and thoughts to not to take actions that may harm others and can provoke conflicts (Nor et al., 2018). Humans, as social creatures, are inseparable from social problems that surround them, and the way they get along with each other is diverse. So does in dealing with social problems, one group challenges them in positive, constructive ways while the other considers them a potential obstacle (Abdullah, 2017). Thus, to establish peace requires serious and systematic efforts to realize a sense of justice and security, not only among individuals but also groups to avoid both physical and economic threats (Gada, 2016).

Peace has become one of the focuses of the United Nations Educational, Scientific and Cultural Organization (UNESCO)'s Declaration and Program of Action on a Culture 
of Peace. According to UNESCO, the characteristics of peace are (1) dynamic, (2) a fair solution to problems without violence, (3) producing balanced social interactions to develop harmonious relations, (4) good for society, (5) no peace if there is violence, (6) no peace if there are injustice and freedom, and (7) to create balanced social interactions, peace must stand on justice and freedom (UNESCO, 1996).

This research intends to examine the context of Muslims' contestation in Salatiga, and observe how Muslims in Salatiga live to establish peace among religious believers. Salatiga is a small but great city located at an intersection of three big cities: Semarang, Surakarta, and Yogyakarta. Different from the aforementioned three cities, Salatiga has a mild atmosphere since it is located in slopes. The most interesting about Salatiga is that this city has a strong culture of tolerant. SETARA Institute for Democracy and Peace, an Indonesian non-governmental organization, granted Salatiga as the most tolerant city in Indonesia in 2020 (SETARA Institute, 2020). Salatiga previously gained the predicate as the top ten most tolerant cities in Indonesia for three consecutive years. It thus makes Salatiga a reference for other cities in the context of religious life. It is also clear that even though Salatiga is a small city, the level of tolerance is higher than other big cities in Indonesia. Therefore, one can find patterns of unique and dynamic interactions within inter-religious communities in Salatiga in terms of peaceful life among religious believers. Although Muslims constitute the majority, they can live in peace and co-exist with other religious believers. In fact, harmonic coexistence has been practiced since decades ago (Darmastuti et al., 2019). 
Salatiga has been regarded as a miniature of Indonesia primarily because the city has a fairly high level of religious plurality. It can be seen from at least Indonesian official religions thrive peacefully in the city: Muslim (77\%), Protestant (17\%), Catholic (5\%), and Buddhist, Hindu, and Confucian (1\%). More than thirty-three ethnic groups coexist harmoniously in the city. An important factor seems to be the tolerance culture inherent within its people. An example of this attitude is where mosques and churches facing each other, for example, in Pancasila Square, Pandawa Mosque faces the Indonesian Christian Church (GKI) of Salatiga. Additionally, Salatiga citizens have experienced of being led by non-Muslim mayors, such as Mayor John Manoppo, where there were no protest nor resistance regarding his religion. The majority of people in Salatiga have used to live in diversity due to the continuously positive exposition from their surrounding environment. Moreover, the existence of two religious-based educational institutions, such as Satya Wacana Christian University (UKSW) and the State Institute of Islamic Studies (IAIN) Salatiga, witnesses the existing city's plurality (Putra et al., 2019; Ali et al., 2020).

This research aims to explain how and why the peaceful life in Salatiga has survived to the present day. Are there any factors that support and influence the community to remain in a peaceful life, although they practice different religions? This research takes into account the way some Muslims link their understanding of Qur'an verses to their practical attitudes towards a peaceful religious life. This research will also observe and analyze variations within the relationship among religious believers to uncover the dynamic interactions within the religious communities. 
The main claim to be elaborated in this research is that there are variations in the relationship among religious communities. Specific ideas and practices of Muslims in Salatiga will become the main analysis of this research. The society has a common view about the importance of building a peaceful life, but the religious believers have their own way to initiate and address the issue of peace. Furthermore, to explain a more massive relationship to the pattern of peaceful interactions among religious believers, an in-depth research on the terms of peace in the Qur'an is crucial as a basis of ideality and framework indicator. For this reason, the research focuses on the socio-thematic interpretation of the Qur'an will describe several terms such as: al-salam (peace of mind and harmony), al-sulh (elimination of hatred between human beings), and al-aman (safety, protection, and calm in the social context).

Based on the above background, this research aims to answer several questions: (1) what is the approach of sociothematic interpretation to the themes of peace in the Qur'an related to the perspectives of Muslims in Salatiga upon the peaceful life among religious believers? (2) how have ideas and practices of Muslims in Salatiga supported the formation of a peaceful life among religious believers? and (3) in what way can one explain motives and efforts of the society to support the peaceful life in Salatiga? These objectives are expected to be able to illustrate the positive correlation between the Muslims' attitudes toward the Qur'anic interpretations and their practical attitudes toward a peaceful life among religious believers in the city. 


\section{B. Research Method}

This research combines literature review and semistructured interviews to gather data based on social responses and literature of contemporary Qur'anic interpretation. The former is useful as a preliminary research on the concept of peace in Islamic teachings (the Qur'an and Hadith) to strengthen theories used in the study (Moleong, 2007). The data obtained through the literature review will then be analyzed and compared with the reality found during the research. Next, data collection was continued with interviews to investigate research subjects' perceptions using the purposive sampling method where researchers determine the research subjects based on the assumption if the collected data are adequate. The field data were designed to explore the perspectives of Muslims' about the topic which are reflected in their mundane life.

The research subjects for interview are (1) Muslims living in the same house with non-Muslim family members, (2) Muslims with non-Muslim neighborhood, (3) religious figures, and (4) non-Muslims with Muslim family members. These samples were selected based on the principle of data representation and the research focus. The interviewees will be interviewed about the meaning of peace, the concept of peaceful living with other religious believers, forms of tolerance they usually practice, and views on other religious communities. Basically, the interview is conducted in a semistructured style where the interview will be considered completed if the data obtained is deemed to have been fulfilled, or vice versa (Berg \& Lune, 2017). The purpose of the interview is to explore perceptions, motivations, and practices 
of tolerance, and the culture of peaceful living developed in the community to discover a special meaning of Qur'anic terms related to peaceful life.

The strength of this research lies on the accuracy understanding about verses on peace obtained from various existing interpretations. It is then collaborated with the results of the socio-thematic interpretation approach to peace and how it forms peace within the Muslim community in Salatiga. The collected data from interviewees will be the landscape of the research results which then is described as simply as possible using a schema. It is a special feature of the hermeneutical approach of socio-thematic interpretation to the Qur'an by combining perspectives in aspects of the unity of the Qur'an themes. It is done by conducting an indepth analysis of the context on the ground: practices, understanding, and culture in society (Hanafi, 2006).

\section{Basic Concept of Peace in the Qur'an}

The word 'peace' is an adjective that means no war, safe, calm, harmonious, no riot, and security or protection. The word refers to information about the condition where an individual or a group living a life. Furthermore, the word 'peace' is a lemma which then forms the term 'peace' (noun) after an affix is attached that means the active process of building peace and cessation of hostilities. More precisely, 'peace' is used to describe individual or group efforts in building a peaceful life. On the other hand, 'peace' with the additional affinity, 'peace' (noun) implies describing a situation i.e. "a state of peace and a safe life" (Saged, 2021). 
Furthermore, in Arabic, the term 'peace' can be traced in the Qur'an both as a peaceful condition or atmosphere and to understand the binary opposition of conflicts. Some of important terms include al-salaam, al-sulh, al-aman, and ma'ruf(Shihab, 2004). This research presents a comprehensive perspective on peace through greetings in various derivatives without leaving other key terms since they are interrelated.

The word al-salaam means peace or harmony. Peace (al-salam) is viewed as an outcome and a life goal to be achieved only after submitting fully to the God's will. Peace may be every Muslim's life goal as explained in surah Yunus [10]: 25 where Allah invites mankind to Dar al-Salam (land of peace). Moreover, Al-salaam means to maintain security and peace as indicated in surah al-Hasyr [59]: 23. Another meaning of salaam may be more implicative for the society's welfare as in Hud [11]: 48, or a greeting as a part of rewards for those who enter paradise (see surah al-Nahl [16]: 32; Qaf [50]: 34). Peace (al-salaam) also requires effort as explained in surah al-Ra'd [13]: 24 that patience is one aspect of peace (see surah al-Anfal [8]: 61). Furthermore, the term al-salaam can be understood as a form of salvation, for example when prophet Ibrahim was saved from fire by Allah (see surah AlAnbiya [21]: 69). Thus, 'peace' has an internal, personal, and social applications, and God is the source and maintain such peace (Abu-Nimer, 2000).

In addition, the Qur'an uses word al-salaam for greeting and praying. The word as-salaam consists of three letters sinlam-mim, forming a root word (masdar) salaama. The word al-salaam is basically originated from the same root word as Islam i.e. aslaama (Faris, 1979) that both mean submission 
or peace. In the Qur'an, the word formed by letters sin-lammim is repeated 440 times where the most common one is salâamun/salâamin (392 times). The word al-Islam is repeated throughout 6 verses, and as-salaam 42 times (Abd. Baqi, n.d.).

Besides the Qur'an use the word al-salaam as a representation of peace, the word al-sulh, derived from the word salaha-yasluhu-salhan, is also used meaning "detached from corruption" or "eliminating hatred among humankind" (Faris, 1979). The verb, saluha-yasluhu, means to be good and beneficial or to prevent damage. The root word can also form aslaha-yuslihu (see surah al-Nisa [3]: 114) that means to repair something damaged, to reconcile, and to make something useful and helpful (Al-Thabari, 1992). Additionally, al-sulhu can be understood as a way of peace such as in surah al-Nisa [3]: 128 which explains about peace building among human beings. Al-sulh also means an effort to directly stop the dispute (to cut off a polemic) or through a neutral third party (surah al-Hujurat [49]: 10). In the modern perspective, the word al-sulh or ishlah means reconciliation referring to efforts towards peace called a pious action (Esposito, 1995). The verb saluha does not require an object while in the Qur'an the word sulh is mentioned 180 times and salih (isim fa'il or the doer of saluha) is 137 times where 46 of them as a mufrad and 9 times refer to the Prophet (Abd Baqi, n.d.).

Subsequently, the term al-aman is taken from amana meaning a peaceful heart, safe conditions, protection or security, calm and prosperous (Faris, 1979). More specifically, the word al-aman in the context of peace is mentioned 17 times and is always associated with a country's safe condition 
and an absence from war (Abd Baqi, n.d.). It is also noticeable that al-aman refers to the protection from being scared as depicted in surah Quraisy [106]: 4. In addition, the word alaman also has the same letters as al-iman meaning that if one establishes have faith only in God their feelings and life will be safe and prosperous (Ar-Razi, 1992).

Another derivational form is the word ma'ruf, a noun (ism maf'ûl) of the word 'arafa. According to Faris (1979) the word 'arafa means "continuous and calm." The root word can form several derivational words such as a'raf ("the sound of a horse"), ma'rifah ("knowledge" because those who have knowledge will be calm), 'arf ("fragrant" because it will please those who smell it), 'urf ("kindness" because it calms calm, and "tradition" because it makes people happy), and i'tarafa ("to admit") (Ridha, 1990).

Al-Qurthubi (1992) synchronizes the meaning of 'urf, ma'rûf, and 'arifah which are all characteristics accepted by common sense and calm the soul. In the Qur'an, the word ma'rûf and its derivations are mentioned 13 times altogether with munkar, while the mere ma'ruf71 times and al-ma'ruf 39 times (Abd Baqi, n.d.). Although the words convey a number of meanings, the meanings can be considered relatively similar that is to create and sustain harmonious and peaceful mind. Surah Al-A'raf [7]: 199 and Al-Mursalah [77]: 1 exemplify the context where the words connote an order to provide a virtue and righteousness. It can be drawn that the command to do a good deed can be by seeking forgiveness to build harmony.

Ideally, the doctrine of peace in Islam can be understood through three basic aspects. First, theological doctrine (theocentric) teaches that God is the Most Peaceful 
as manifested in al-asma' al-husna, al-salaam (the most peaceful). Therefore, all practices and teachings from God always prioritize harmony and peace above anything else. Second, prophetic doctrine teaches that all prophets always convey their treatises by promoting and building peace as one of important points in establishing social transformation (Nor et al., 2018). Thus, peace should be realized by each believer (Hisyam, 1971). Third, anthropocentric doctrine teaches that historical facts record the progress of civilization through the level of peace within the society. Ibn Khaldun (2015) asserts that human should be interconnected to fulfill their sociological needs. Human basic needs for social interactions serves as an important foundation for humanity to maintain a peaceful life (Khairulnizam \& Saili, 2009).

All in all, the concept of peace in the Qur'an basically refers to an active and dynamic context that encourages people to maintain the values of peace by respecting all forms of diversity and reaching a peace agreement. Thus, the concept of peace according to the Qur'an is not passive indicating the absence from war or chaos but it is a dynamic condition that is constantly changing. Therefore, the culture of peace displayed by Muslims in Salatiga should also be understood in a dynamic, straightforward, and continuous context. The contestation of Muslims in Salatiga in presenting the culture of peaceful living will be constructed in every aspect of the social life.

\section{Ideas of Muslims in Salatiga about Peaceful Life}

Through the interviews, this research attempts to understand the meaning of living peacefully from the 
perspectives of Muslims in Salatiga, especially those who live amidst religious diversity. Therefore, it should be underlined that the construction of a peaceful life is not merely understood as a condition of the absence from war, riots, and conflict. However, according to Omar (2013), living in peace is a positive effort that should continuously maintain values of harmony, prosperity, freedom, and justice to remain intact and attached to the society. Hence, peace will make the community live life calmly, safely, and productively.

Academically, the idea of a peaceful life may be understood in a negative or positive framework. Negative peace is a form of artificial peace where it indicates the absence from conflicts only on the surface because of the absence of power asymmetry and strong conflict of interest (Omar, 2013). This peace model can be considered more similar to the concept of a time bomb, where at any time, it may lead conflict to the surface. On the other hand, positive peace is more preventive and progressive in understanding the concept of peaceful life. It is a condition that requires the existence of a non-coercive conflict resolution to prevent conflicts from coming to the surface (Nor et al., 2018). This model also requires a comprehensive perspective including the absence of conditions that suppress or threaten humankind, which cover a broader spectrum: from fulfilling and guaranteeing the needs for lahiriyah (physic) and batiniyah (psychology) (Mutawali, 2016).

In the context of the idea of peaceful life in Salatiga, this research confirms that one's self-concept develops through their interactions with other communities (Berger \& Luckmann, 1991). Therefore, a society that has long lived in 
religious and cultural plurality will be more tolerant compared to those living in a homogeneous community. This is evident that citizens of Salatiga tend to be more open-minded and friendly towards other religious believers (Darmastuti et al., 2019). There may be no difference in attitudes and tendencies based on religious differences. According to them, the concept of peaceful life includes at least eight types of attitudes such as tolerant, good cooperation, grateful, minimizing conflict, no pressure feeling, harmonious, mutual respect, and awareness of two forms of relationship: vertical (God) and horizontal (human/nature and all creatures).

Ideas of Muslims in Salatiga collected through interview process have been summarized in the following table:

Table. The Concept of Peaceful Life

\section{Informants}

Muslim living with non-Muslim family members

\section{Non-Muslim living with Muslim family members}

Muslim who lives in non-Muslim neighborhood

\section{Meaning of Peaceful Life}

There should be a strong tolerance Able to pray five times a day without being scared

Able to use any place to pray

Able to perform prayer

Able to locate some religious symbols Having strong feeling each others

Casually interact with each other Giving some food and visiting each other Allowing children to play together with non-Muslim's children 


\begin{tabular}{l|l|} 
Religious figure & $\begin{array}{l}\text { Relationships among people must be } \\
\text { harmonious } \\
\text { Presenting universal values of religion } \\
\text { Respect for interfaith communities }\end{array}$ \\
\hline $\begin{array}{l}\text { Head of } \\
\text { society }\end{array}$ & $\begin{array}{l}\text { Have a vertical relationship with God } \\
\text { simultaneously with humankind, nature } \\
\text { Mutual understanding and cooperation } \\
\text { Mutual cooperation among religious } \\
\text { believers }\end{array}$ \\
\hline
\end{tabular}

Based on the above table, it can be concluded that there is a common perspective in the importance of realizing a peaceful life and prioritizing the formation of a peaceful life than highlighting differences. It also can be understood that some ideas such as tolerant, respect, avoiding conflict, and cooperative are fundamental aspects for constructing the discourse of peace among people in Salatiga.

\section{E. Types of Motives, Tendencies, and Reasons Muslims in Salatiga Live in Peace with Other Religious Believers}

Numerous researches describe that similar tendency can be a motive to establish a peaceful life in a community of religious believers. Among the roles of religious leaders are to maintain the continuity of peaceful life and post-conflict reconciliation efforts (Suprapto, 2015). Four types of motives of peaceful life will be elaborated in the following paragraphs.

The first motive explains that one respects others' faiths due to political considerations. It may be owing to national interests, for instance, since they live in one country 
the religious believers should be able to live peacefully for a common goal (Rehman, 2011). The community realizes that the state is a shared property and is a shared responsibility of religious communities. This motive can be constructed by the government through seminars, interactive dialogues, outreach programs and other imperative forms (Al-Qurtuby, 2012). However, it should be underlined that the peaceful attitudes formed through the above activities are often superficial and fragile, and even easily provoked by religious emotions. It is not even possible for a person or group to sacrifice shared ideals merely due to offending religious emotions.

The establishment of FKUB (Forum for Religious Communication) also plays a significant role. The forum provides consultations and dialogues on interfaith issue to foster peace and support the government interests (Mujiburrahman, 2008). The forum also facilitates cooperation among religious believers. For example, if there is a conflict in the community FKUB serves as a reference and support to prevent further tensions and violence. FKUB usually works closely with the police and the local government to strengthen their role in the community (Panggabean \& Ali-Fauzi, 2015).

The second motive suggests that thorough understanding of the urgency of social interactions based on humanity may be an important reason for people to live peacefully (Khaldun, 2015). Muslims in Salatiga realize that neighbors may provide space for them to bring about peace. In the social life, neighbors are those living closest by distance while for Muslims in Salatiga, neighbors are the closest relatives. Their homes in the community are in the front, back, right and left sides. Their attitude to live with neighbors 
is like one family. Neighbors are also seen as a part of relatives as they are closer and can meet and interact every day (AlBukhari, 1999). Therefore, by understanding the urgency and neighbors' roles in life, Muslims in Salatiga can comprehend that different religions cannot be an obstacle to live together and help each other. They also understand human can interact positively not because of religious motives but humanitarian ones (Darmastuti et al., 2019).

The society carries out several activities that constitute to peace building such as visiting each other, playing game, socializing, and participating in community activities together. These community activities include during religious celebrations, traditional ceremonies, harvest time, commemoration of Independence Day, etc. Similarly, children are also accustomed to play together with those having different religious beliefs in the villages and schools (Putra et al., 2019).

The third motive is similar interests and preferences that construct a peaceful life based on a common interest or similar habits/preferences. In addition to daily life, many religious communities participate in organization-based group activities, such as political parties and non-religious voluntary community organizations, e.g. clubs on culture, arts, hobbies, or sports. Involvement in organizations also includes those engage in trade and business such as trade unions, small business groups, and other members although they embrace different religion. Such involvement in organizations and associations plays an essential role in fostering peace compared to daily interactions with neighbors. At this level, thus, the community may not consider religion or beliefs as their basis in every action (Putra et al., 2019). 
The fourth motive explains that both genotype (innate) and phenotype (environmental) factors play a major role in shaping the characteristics of tolerant societies. In the perspective of social science, community personalities are characteristics resulting from interactions between biopsycho-fiscal potentials: given physical and psychological potentials in a series of environmental situations reflected in actions and mental psychological reactions when they are stimulated by the environment (Berger \& Luckmann, 1991). Therefore, heterogeneous elements of society train citizen of Salatiga to be able to socially interact with other religious believers. Salatiga have been recorded as a plural city since hundreds of years ago where mosques and churches facing each other can be easily found throughout the city. This condition according to Saerozi (2017) will form a culture and structure of strong tolerance in the community.

Social structures in terms of behavioral patterns and tendencies can be passed from generation to generation which lead people experience such patterns. It may also lead to togetherness and kinship among religious believers deeply rooted in the society's culture (Abdullah, 2017). These four motives drive the community to realize a peaceful life among religious believers. These tendencies have subsequently changed to something 'ascribed': common things which may not even be thought by the public. In a later stage, people may have entered the 'unaware' process where they may be not aware that they interact with people of different religions and only think that they interact with fellow human beings (Ali et al., 2020). 


\section{F. Practical Contestations of Peace Culture in Salatiga}

Ideas on peaceful living not only can be positively described but also support the patterns of peaceful cultural construction among religious believers. Unlike Syarif \& Muhtadi (2018) who divide Muslim-Christian interactions in Sindang Jaya, Cianjur, Indonesia, into four forms of dialogue (life dialogue, social dialogue, religious or theological dialogue, and dialogue on religious experience), this research focuses specifically on patterns of sociological interactions.

The peaceful life construction in Salatiga can be traced through three aspects of social interactions such as how their peaceful life activities take place within religious activities, social activities, and their participations to support government programs. This construction plays a crucial role as a framework that can construe their social experiences. In the cognitive framework, this construction helps them reach environmental integration and arrange social reality (Omar, 2013), and will further affect the formation of peace life for each individual/community which is multicultural.

1. Muslims in Salatiga lead a peaceful life by expressing their socio-religious life in the public sphere.

Activities can be diverse such Halal bi Halal and Christmas celebrations. During the celebrations of the two religions, both Muslims and Christians helped each other to succeed the event. For example, in Halalbi-Halal, the organizing committee like Master of Ceremony (MC) used to be selected from Christians (Erlisa, personal communication, 2020). Likewise, in other Islamic Holidays (PHBI) such as Eid al-Adha where 
non-Muslim communities in Salatiga are accustomed to assisting technical implementations e.g. cutting the sacrificial and distributing to those in need regardless of religious background.

Moreover, during the celebration of Eid al-Fitr, Halal bi Halal is usually held in every neighborhood association where the Muslim community never forgets to invite non-Muslim to attend the event. Muslims realize that mistakes made between fellow human beings, direct and indirect interactions, should be forgiven (Suwarsi, personal communication, 2020). Hence, Halal bi Halal can be seen as the right moment to re-establish harmony and improve relations between the people (Faidi, 2020). It is this awareness that drives Muslims in Salatiga to feel the need to invite non-Muslim to seek for their forgiveness. In fact, community traditions such as yasinan and tahlilan (assembly of reciting surah Yasin and tahlil), non-Muslim are always invited and attend those activities. Non-Muslim may only act passively in those events such as attending, sitting, and quietly listening to the activities. Likewise, non-Muslim women appreciate the sacredness of those activities by using a veil or headcovering as a formality. Conversely, during Christmas or other religious celebrations, Muslims help these activities such as cooking, cleaning, preparing the place, etc.

2. The social sector is intended as an activity from the citizens' initiative

Social activities including social services, healthy environmental movements, celebrations of Indonesian 
Independent Day, mutual cooperation, interfaith hospitality, and other creative socialactivities are activities combining the harmony of each society's element without questioning social and religious differences. These activities may be commonly triggered by anxiety or a similar feeling towards a certain environmental condition. For example, to create a healthy environment, the community initiate cleaning the environment together and some residents may provide some food. All people seem harmonious when they are eating together, having chat, and making jokes each other (Hartawati, personal communication, 2020). The beauty of this moment is very expensive and rare where it may only be united by humanity and leaving all forms of differences. Interfaith relations across the legal thoughts (madzhab), tribes, and nations can be seen as an important social capital for the development of human civilization.

3. Muslims in Salatiga run governmental social programs to build a peaceful life

Government plays an important role to drive society in establishing positive patterns of interactions, for example, through the PKK (Family Welfare Empowerment) program, community clinics, and RT/RW (neighborhood associations) (Supriyadi, personal communication, 2020). Since these interactions in those activities are based on the government, the interactions developed tend to be 'political' or a mere of a structural obligation. This pattern of peaceful life is also very important to support the construction of a peaceful life in Salatiga. 
The above activities have become daily practices for Muslims in Salatiga, and even a tradition or new culture for religious believers (Ali et al., 2020). This kind of peaceful life construction reflects real positive and cooperative actions because it is filled with a spirit of togetherness. It also becomes the foundation of the Salatiga's religious level to reach the maturity level where the people can gather, help each other to fulfill their basic needs, and socially interacting or gregariousness (an instinct or human consciousness to unite and live together with other human beings). In sum, this research reaffirms Burhanudin's (2010) findings that the Muslims' tolerance level in Java is relatively high.

Sociologically, the functional relationship between religion and society can emphasize the aspects of rational and harmonization which will lead the community to development. The pattern of interactions built in the community, both in the city and at the village level, show healthy communication and tend to lead to unity (Ridwan \& Robikah, 2019). In general, harmony between religious believers in Salatiga can be said to be very good and conducive. Each still holds to the principle that all religions teach their adherents good things or truths including religious tolerance which leads to religious pluralism (Putra et al., 2019).

Based on the ideas and practices on the concept of peaceful life in Salatiga, it can be understood that those are the core values supporting the realization of peaceful life among religious believers. These values may be relative and tentative, but they are mutually sustainable 
and supportive. Such values are (1) honesty meaning the willingness to share the truth and trust each other, (2) freedom meaning to have the freedom to embrace any religion without any intervention and coercion from other parties, and (3) respect meaning the willingness to respect and appreciate other religious believers for all their worship and daily lives (Arifin, 2016). These three values serve as the fundamental basis in the contestation of peace among religious believers in Salatiga.

Furthermore, these values transform to love or mutual compassion for others without questioning their religious background, and to peace where it supports any peace efforts and avoid all forms of conflicts that may occur in society. These values require others' appreciation to acknowledge the existence and truth of other religions. They should believe that every religion teaches the truth and universal goodness. Unity is an integral part connecting the previous values which means commitment to unite in differences and promoting equality. Surah Al-Hujurat [49]: 13 mentions that peace will only be created if the relationship between human beings is based on love, mutual respect, and prioritizing brotherhood (ukhuwah basyariyah/unity of humankind).

The whole set of values is a source of peace, namely tolerance, which embodies acceptance of other religious believers to interact and live in harmony altogether. Tolerance is the core value to construct peaceful life and a method for achieving a common goal i.e. awareness to cooperate and collaborate each other to achieve happiness. Based on the data collection, the construction 
of peaceful life among religious believers can be illustrated in the figure below.

\section{Figure. The Structure of Peaceful Cultural Construction}

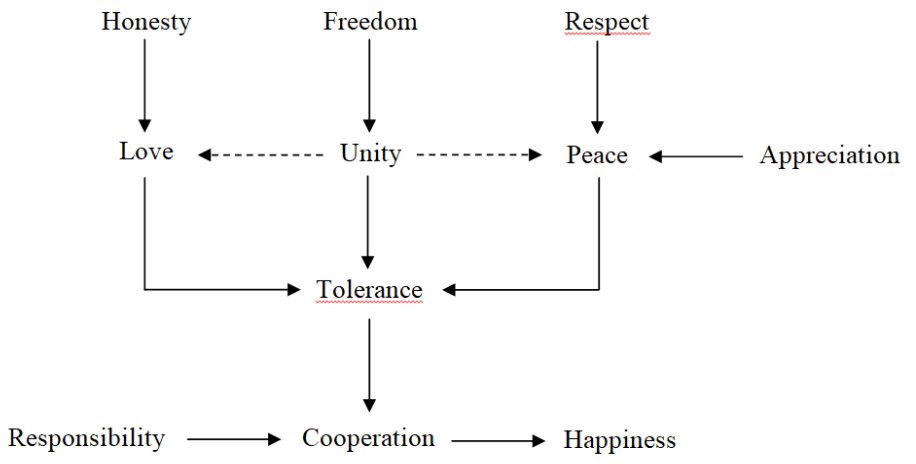

Source: collected data

Based on the above scheme, it can be concluded that the construction of peaceful culture in Salatiga is entirely based on the ideas and practices of tolerance which lead forms to cooperation among religious believers. Thus, this study identifies derivations of the meaning of tolerance from the Quranic verses in the public sphere. The Muslim contestation in Salatiga in applying a peaceful life is fully manifested in tolerance practices. More specifically, tolerance according to the Salatiga community is not only respecting diversity butalso a method to realize a peaceful life. Similarly, Abu-Nimer (2000) states that peace in Islam is a state of physical, mental, spiritual, and social harmony. Living at peace with God through submission and with fellow humans by avoiding mischief on the earth are the real Islam. Islam is a religion that preaches and obligates its believers to seek peace in all life's domains. It is true that even though Muslims in Salatiga are the 
majority, but they do not intend to discriminate the other believers and are able to construct a peaceful life in the public sphere. This atmosphere may be hardly found in other cities in Indonesia where Muslims are the majority. Instead, there is a tendency that the majority of Muslims are relatively close to intolerant practices. Concerning the preventive aspects of inter-religious harmony, two factors should be considered. First, the social structure and the community's religious experience reflected in the form of positive-constructive dialogue can be important points to construct a culture of peaceful life in the public sphere. People who are conservative and do not want to make progress tend to defend their conservative ideas or perspectives, are close-minded, and look at a problem only from one side such as their notions and groups (Burhanudin, 2010). If it happens, the dispute will easily arise and eventually spread out of control. This kind of problem is often overlooked by the local government where they should study the structure, the problems, and the people in their area more deeply. By doing so, it aims at being able to quickly respond to an occurring problem that potentially develop into a bigger problem.

Second, the community's level of education also needs attention (Karama \& Khater, 2020). The higher the community's education, the easier they will sort out things to be responded or not (Nor et al., 2018). On the contrary, the lower one's education, the narrower and simpler their mindset will be so that they do not want to think out of the box. Generally, people with relatively low level of education tend to be exclusive both in their religious 
thoughts and actions. If a community has a balanced education, different opinions among religion believers can be avoided since they have been able to sort out what they should do and not (Ozman, 2007). Likewise, through religious activities, people tend to respect each other and do not influence each other. It may happen because they believe that each religion has a good purpose and always teaches towards good rather than bad.

\section{G. Conclusion}

Islam teaches peace as a principle of human relations by associating the word Islam to the meaning of peace, particularly among those who declare that being a Muslim should embody peace as a principle of social interaction. This kind of understanding is seen to be effective to construct a peaceful life in the public sphere. Muslims in Salatiga, for instance, set peace as a pillar and an important life goal. They realize that a peaceful life is a natural way of life, wherein as a Muslim one should be able to be a pillar in building a peaceful life within society. It is also generally reflected in the culture of Salatiga where people live in peace although they have to live side by side with other communities. The diverse cognition system of the people in Salatiga may be a positive element because they can understand and cooperate with each other. The culture of peaceful living reflected in Salatiga community is multidimensional where peace is embedded in the spiritual, physical, and social aspects of interactions.

Byapplying anapproach of socio-thematicinterpretation to the Qur'an, this research reaffirms the agreement and the contestation of the concept of peace on the reality in a 
peaceful culture in Salatiga. This research seeks if the peaceful culture is purposefully directed to the Qur'anic terms. Values such as harmonization, tolerance, and togetherness are still dominant ideas in the public space, whereas practices such as cooperation, friendship, and helping religious believers are activities that can be seen in their daily life. This pattern can be derived from the view of sociological Qur'anic interpretation.

\section{References}

Abd Baqi, M. (n.d.). Mu'jam al-mufahras li al-fadzi al-quran alkarim. Darul Hadist.

Abdullah, M. (2017). Islam as a cultural capital in Indonesia and the Malay world: A convergence of Islamic studies, social sciences and humanities. Journal of Indonesian Islam, 11(2), 307-328. 10.15642/IIIS.2017.11.2.307-328

Abu-Nimer, M. (2000). A framework for nonviolence and peacebuilding in Islam. Journal of Law and Religion, 15(1), 217-265. https://doi.org/10.2307/1051519

Al-Bukhari, M. (1999). Shahih al-bukhari. Riyadh: Darussalam.

Al-Qurthubi, M. bin A. A. B. bin F. (1992). Al-jami li ahkam alqur'an. Beirut: Dar al Fikr.

Al-Qurtuby, S. (2012). Catholics, Muslims, and global politics in Southeast Asia. Al-Jami'ah, 50(2), 391-430. https:// aljamiah.or.id/index.php/AJIS/article/view/147/67

Ali, M., Sofyan, M. A., \& Arenggoasih, R. W. (2020). Contestation behind tolerance: between competition and tolerance in the discourse of multiculturalism in. Jurnal Ilmiah Islam Futura, 20(2), 166-180. http://dx.doi.org/10.22373/ jiif.v0i0.5835 
Ar-Razi, F. (1992). Tafsir al-kabir wa mafatih al-ghaib. Beirut: Dar al Fikr.

Arifin, S. (2016). Islamic religious education and radicalism in Indonesia: strategy of de-radicalization through strengthening the living values education. Indonesian Journal of Islam and Muslim Societies, 6(1), 93-126. https://doi.org/10.18326/ijims.v6i1.93-126

Berg, B., \& Lune, H. (2017). Qualitative research methods for the social sciences, global edition. New York: Pearson Education Limited.

Berger, P., \& Luckmann, T. (1991). The social construction of reality: A treatise in the sociology of knowledge. New York: Penguin Books.

Burhanudin, J. (2010). Survey report: a portrait of muslims' socio-religious attitudes in java. Studia Islamika, 17(1), 195-198. https://doi.org/10.15408/sdi.v17i1.472

Darmastuti, R., Winarso, S., Edi, M., \& Christianto, E. (2019). Understanding the meaning of self-identity construction of Salatiga community memahami makna konstruksi identitas diri masyarakat salatiga. Jurnal The Messenger, 11(2), 232-243. https://journals.usm.ac.id/index.php/ the-messenger/article/view/1273/1011

Faidi, A. (2020). Pendidikan toleransi terhadap remaja Muslim dan Kristen di Salatiga (Studi terhadap perayaan halal bihalal dan natal bersama di desa Pengilon Mangunsari). Intiqad: Jurnal Agama Dan Pendidikan Islam, 12(2), 134-150. http://dx.doi.org/10.30596\%2Fintiqad.v12i2.5089

Faris, I. (1979). Mu'jam maqayis al-lughah. Beirut: Dar al Fikr.

Gada, M. Y. (2016). On pluralism, religious 'other', and the quran: A post september-11 discourse. Indonesian Journal of Islam and Muslim Societies, 6(2), 241-271. https://doi.org/10.18326/ijims.v6i2.241-271 
Hanafi, H. (2000). Islam in the modern world: Religion, ideology and development vol. I. Cairo: Dar Kabaa.

Hanafi, H. (2006). Culture and civilizations, conflict or dialogue? Vol. I the meridian thought. Cairo: Book Center for Publishing.

Hisyam, A. M. ibnu. (1971). Shirah nabawiyah. Beirut: Darul Kutub al-Ilmiyyah.

SETARA Institute. (2020). Ringkasan eksekutif indeks kota toleran. Jakarta: SETARA Institute.

Interview with Agnes Hartawati, someone who lives with neighbor other religious believers. (2020).

Interview with Erlisa, a Muslim who lives with non-Muslim family members. (2020).

Interview with Sri Suwarsi, a Christian who lives with Muslim family members. (2020).

Interview with Supriyadi, a religious figure. (2020).

Karama, M. J., \& Khater, N. A. (2020). Educational peace theory in the holy qur'an. Al-Bayān - Journal of Qur'ān and Hadith Studies, 18, 138-154. http://scholar. ppu.edu/bitstream/handle/123456789/2214/1. pdf? sequence $=1$ \&isAllowed $=y$

Khairulnizam, M., \& Saili, S. (2009). Inter-faith dialogue: The qur'anic and prophetic perspective.Journal of Usuluddin, 9(2), 65-94.

Khaldun, I. (2015). Muqaddimah. Cairo: Dar-Ibnu al-Aitam.

Moleong, L. (2007). Metodologi penelitian kualitatif (edisi revisi). Bandung: PT Remaja Rosdakarya. 
Mujiburrahman. (2008). State policies on religious diversity in Indonesia. Al-Jami'Ah, 46(1), 101-123. https://aljamiah. or.id/index.php/AJIS/article/view/80/103

Mutawali. (2016). Moderate Islam in Lombok: The dialectic between Islam and local culture. Journal of Indonesian Islam, 10(02), 309-334. 10.15642/IIIS.2016.10.2.309-334

Nor, M. R. M., Khan, I., \& Elius, M. (2018). Analysing the conceptual framework of religious freedom and interreligious relationship in Islam. Indonesian Journal of Islam and Muslim Societies, 8(2), 309-334.

Omar, M. (2013). The concept of peace in the qur'an. 3(4), 1934.

Ozman, Z. (2007). Some reflections on islamic view of other divine religions within the context of inter-religious dialogue. Journal of Religious Culture, 91(2), 1-7.

Panggabean, S. R., \& Ali-Fauzi, I. (2015). Policing religious conflicts in Indonesia. Jakarta: Center for the Study of Religion and Democracy (Pusat Studi Agama dan Demokrasi, PUSAD) Paramadina Foundation. https:// www.neliti.com/id/publications/787/policingreligious-conflicts-in-indonesia

Putra, A. D., Purnomo, D., \& Utomo, A. W. (2019). Sociological study of harmony in diversity: Lessons from Salatiga. Walisongo: Jurnal Penelitian Sosial Keagamaan, 27(1), 69-98. 10.21580/ws.27.1.3504

Rehman, U. (2011). Conflict resolution and peacemaking in Islam: Toward reconciliation and complementarity between western and muslim approaches. Islamic Studies, 50(1), 55-69. 
Ridha, R. (1990). Tafsir al-mannar. Beirut: Dar al Fikr.

Ridwan, M., \& Robikah, S. (2019). Ethical vision of the qur'an: Interpreting concept of the qur'anic sociology in developing religious harmony. Jurnal Ilmiah Islam Futura, 18(2), 308-326. http://dx.doi.org/10.22373/jiif. v19i2.5444

Saerozi, M. (2017). Dynamics of the development of istiqomah mosque in front of a church in Ungaran Central Java Indonesia. Journal of Indonesian Islam, 11(02), 423-458. 10.15642/JIS.2017.11.2.423-458

Saged, A. A. (2021). Honoring the human self with a world peace study in the light of purposes the holy quran. Quranika: Journal of Libahuts Qur'an, 19(2), 223-234.

Shihab, M. Q. (2004). Tafsir al-mishbah. Jakarta: Lentera Hati.

Suprapto. (2015). Religious leaders and peace building: the roles of tuan guru and pedanda in conflict resolution in Lombok - Indonesia. Al-Jāmi'ah: Journal of Islamic Studies, 53(1), 225-250.

Syarif, N., \& Muhtadi, A. S. (2018). Interfaith communication. Advances in Social Science, Education and Humanities Research, 260, 72-77. https://aljamiah.or.id/index. php/AJIS/article/view/53109

United Nations educational scientific and cultural organization (UNESCO). (1996). Records of the general conference. In Records of the General Conference; Declaration of Principles on Tolerance, 28th session. UNESCO. 